\title{
The effect of Lactococcus lactis and Bifidobacterium bifidum probiotics cell free supernatants on the expression of HDC and TDC genes in Staphylococcus strains isolated from milk
}

\author{
Mohammad Ali Masiyan MOGHADAM ${ }^{1}$, Seyed Amirali ANVAR ${ }^{1 *}$ (D), Kumarss AMINI², Mohammadreza KHANI ${ }^{3}$
}

\begin{abstract}
The most important microorganisms contaminating milk, such as staphylococci, exert their influence by producing toxins and biogenic amines (BA). The purpose of this study was to evaluate the influence of cell-free supernatants (CFS) related to the probiotic strains of Lactococcus lactis and Bifidobacterium bifidum on the expression of BA-producing genes, histamine decarboxylase, and tyramine decarboxylase in staphylococci isolated from milk. Staphylococci isolates of cow raw milk were identified and isolated using standard methods. Samples containing these strains were analyzed by HPLC for BA production. Bacteria with target genes were treated with L. lactis and B. bifidum CFS, and the expression of target genes was measured by Real time PCR. Generally, 60 strains of Staphylococcus were isolated, and 90\% of strains had HDC and TDC genes in genome. The levels of BAs were significantly higher on the second and third days after sampling compared with the first day ( $\mathrm{p}<0.02$ ). The analysis RT-PCR indicated that the under expression of target genes was statistically significant $(\mathrm{P}<0.05)$. This study showed that the use of probiotic bacteria can reduce the production of these amines and increase the quality of milk through reducing the expression of tyramine and histamine producing genes.
\end{abstract}

Keywords: histamine; milk; probiotic; Staphylococcus; tyramine.

Practical Application: Milk has long been considered as a nutritious food which contains more than ten vital nutrients including protein, carbohydrates, vitamins, minerals and fats. Histamine and tyramine are very harmful products of milk-contaminating microorganisms specially Staphylococcus spp. Our study evaluated the effect of L. lactis and B. bifidum probiotics on the expression of histamine and tyramine-producing genes of Staphylococcus species isolated from raw milk. Results indicated that the use of these probiotics was effective on the reduction of expression of these biogenic amines.

\section{Introduction}

Nowadays, cow milk and dairy products are among the most important foods in the world; moreover, adequate production and observance of hygienic points in their production and storage stages are of great importance. Milk is one of the most important human needs, especially in childhood; because it is rich in organic matter, it is a suitable environment for the growth of various food-borne pathogens. This indicates the necessity for milk hygiene and elimination of pathogenic microorganisms and their products, including toxins and biogenic amines (Motaghifar et al., 2020; Acu et al., 2021; Amelia et al., 2021; Shabbir et al., 2020; Zendeboodi et al., 2020).

Staphylococcus is a facultative anaerobic round-shaped and Gram-positive coccus; it produces various contaminants, toxins, biogenic amines, and aggressive enzymes and can be found in numerous food products as well as raw milk. Responsible for a variety of symptoms and diseases, this microorganism is known as one of the world's most important causes of disease epidemics associated with food consumption (Zhao et al., 2020). Biogenic amines are very harmful products of milk- contaminating microorganisms. These amines are low molecular weight compounds mainly formed by the decarboxylation of amino acids or amines and transfer of aldehydes and ketones (Poveda et al., 2020). These amines are synthesized by microbial, plant, and animal metabolism. Previous studies have shown that cadaverine, tyramine, spermine, putrescine, and histamine are the most important biogenic amines in raw milk (DurakDados et al., 2020; Gonçalves et al., 2020). Tyramine naturally occurs in a number of foods by the decarboxylation of tyrosine via the action of the enzyme tyrosine decarboxylase (TDC). This substance is formed over time through the breakage of the protein chains, and its level is higher in leftover foods. Histamine is one of the most significant aromatic amines whose production is increased by bacteria undernutrient deficiency because in such conditions, histidine decarboxylation is an additional pathway for energy production (Durak-Dados et al., 2020; Elsanhoty \& Ramadan, 2016; Luengo \& Olivera, 2020).

This biogenic amine causes histamine poisoning, the most common symptoms of which are nausea, shortness of breath, 
flushing with fever, sweating, palpitations, and headache. These two biogenic amines (histamine and tyramine) are important hallmarks of bacterial spoilage that can cause food poisoning. Therefore, it is highly important to identify and reduce their amount in food samples due to their toxicity and use as food quality indicators (Kerry et al., 2018; Ruiz-Capillas \& Herrero, 2019).

On the other hand, probiotics are recognized as natural food preservatives and important factors for preventing diseases, controlling bacterial and fungal contamination, and improving human and animal health. In general, probiotic bacteria affect other microorganisms through changing the $\mathrm{pH}$ and glucose levels of the intestinal environment, secreting enzymes and antimicrobial toxins, changing the expression of pathogenic genes and competition on food intake (Kerry et al., 2018; Zhang et al., 2018; Akarca, 2020; Siang et al., 2019; Mituniewicz-Małek et al., 2019; Lucatto et al., 2020).

Probiotic bacteria are presumed to be beneficial and can inhibit or prevent the production of biogenic amines or act as bactericidal ingredients. Fong et al. (2020) investigated the potentials of probiotic bacteria in manufacturing Douchi, a traditional Chinese food; they demonstrated that biogenic amine levels can be diminished or even removed through the use of fermentation starters composed of probiotic bacteria (Prezzi et al., 2020). Similarly, Capozzi et al. (2012) showed that two L. plantarum strains, namely NDT 09 and NDT 16, are able to reduce putrescine and tyramine in wine by degradation.

L. lactis and B. bifidum are known as the most important probiotics used in the food industry; they are natural intestinal microflora and are widely utilized in the storage of dairy products (Ranadheera et al., 2019; Zhang et al., 2018). This study aimed to examine the effect of $L$. lactis and B. bifidum probiotics on the expression of histamine and tyramine-producing genes of Staphylococcus species isolated from raw milk.

\section{Materials and methods}

\subsection{Sampling and isolation of bacteria}

A total of 100 cow raw milk samples were collected over the course of one month from August to September 2020. In each sampling, $200 \mathrm{~mL}$ milk was taken under aseptic conditions, transported to the laboratory in a portable refrigerator $\left(4^{\circ} \mathrm{C}\right)$, and directly analyzed. Five samples were obtained from milk collection centers of industrial companies with the highest production of dairy products in Tehran province. For the other 95 samples, 5 groups of 19 cow milk farms from Tehran province were randomly selected. Each group of 19 was covered by one of the collection centers of industrial companies, and their milk storage tanks were sampled according to the national standards of Iran. Standard biochemical and Gram staining methods were employed to identify the bacteria in the milk samples. $16 \mathrm{srDNA}$ genomic studies were further used to confirm the differential diagnosis of Staphylococcus species. The identified strains were stored in BHI Broth medium containing $18 \%$ glycerol at $-70^{\circ} \mathrm{C}$.

\subsection{Multiplex PCR}

In order to study the genomics and identify the Staphylococcus species, $16 \mathrm{srDNA}$ sequences of the isolated strains were examined using universal primers. Afterwards, multiplex PCR method was used to identify the bacteria with HDC and TDC genes. DNA extraction was performed by a kit (QIAamp, Germany) based on the manufacturer's instructions. Following quality confirmation by Nanodrop (Eppendorf, Germany), specific primers for target genes were designed by Gene runner software and blasted on the NCBI website to confirm specificity. The primers used in the present study are listed in Table 1 . The temperature steps of the PCR reaction were performed as follows: initial denaturation step at $95^{\circ} \mathrm{C}$ for 5 minutes, 35 cycles, including $95^{\circ} \mathrm{C}$ denaturation for 30 seconds, and primer binding at $56^{\circ} \mathrm{C}$ for 30 seconds. The propagation step was performed at $72{ }^{\circ} \mathrm{C}$ for 1 minute; after 35 cycles, the final propagation step was carried out at $72{ }^{\circ} \mathrm{C}$ for 10 minutes. PCR products were electrophoresed in $1.5 \%$ agarose gel in the presence of positive and negative control; after staining with erythrogel, they were photographed by gel documentation device.

\subsection{HPLC method}

The HPLC method was used to determine samples with the most biogenic amines. The samples from which tyramine and histamine-producing bacteria were isolated were examined by HPLC to determine the bacteria with the highest biogenic amines. Biogenic amine levels were assessed 0, 48, 24, and 72 hours after sampling. Samples were prepared by making minor modifications to the method through acid extraction and derivation. A "Silica for powerful LC separation" column was utilized to measure histamine and tyramine by HPLC. The mobile phase was a combination of water and acetonitrile, and the peaks generated by the device were identified and evaluated at $254 \mathrm{~nm}$. The concentration gradient program was used at a flow rate of $0.8 \mathrm{~mL} / \mathrm{min}$. Next, in a test tube, $5 \mathrm{~mL}$ of acidic extract with $5 \mathrm{~mL}$ of butanol were mixed and vortexed for 2 minutes; this was repeated three times and the organic solvent (butanol) was extracted. Finally, the species producing the most histamine and tyramine were recognized.

Table 1. Primers used to isolate Staphylococcus species containing target genes.

\begin{tabular}{ccc}
\hline Name & Primer sequence & bp \\
\hline Forward HDC & 5'-GAATTACCGATCTATGATGC -3' & 99 \\
Reverse HDC & 5'-ACACCTTTGTTAGCACAAAC-3' & 99 \\
Forward TDC & 5'-CGTTCACAATCAGTTCTT-3' & 166 \\
Reverse TDC & 5'-CCAACTTCTTCTTCCATTTG-3' & 166 \\
\hline
\end{tabular}

HDC: Histamine Decarboxylase; TDC: Tyramine Decarboxylase. 


\subsection{Determination of probiotic CFS MIC}

The strains with the most generated biogenic amines were treated with CFS of probiotic bacteria to specify the effect of these CFSs on the expression of histamine and tyramine genes. Cell free supernatant (CFS) of L. lactis and B. bifidum was prepared according to previous studies (Khiralla et al., 2015; Knysh \& Martynov, 2020). Probiotic isolates were grown in MRS broth for $24 \mathrm{~h}$ at $37^{\circ} \mathrm{C}$. Cell-free supernatant was obtained through the centrifugation of the culture (3000 g, $15 \mathrm{~min}$, at $4{ }^{\circ} \mathrm{C}$ ). The $\mathrm{pH}$ of the supernatant was adjusted to pH 6.5 with $1 \mathrm{M} \mathrm{NaOH}$ and sterilized by filtration $(0.22 \mu \mathrm{m}$ Minisart; Sartorius, Germany).

Using the standard method proposed by the National Committee for Clinical Laboratory Standards (CLSI), the minimum growth inhibitory concentration (MIC) was obtained for each of the bacteria in contact with the CFS of probiotic species. In this method, we used two 96-cell microplates with 12 rows, each containing 100 microliters of tryptic soy broth (TSB). $100 \mu \mathrm{l}$ of probiotics CFS (serial dilution from 56 to $109 \mathrm{gr} / \mathrm{mL}$ ) were poured into each of the three wells on all plates. The microplates were then incubated in a shaker incubator $\left(200 \mathrm{rpm}, 37^{\circ} \mathrm{C}\right.$ for a maximum of 24 hours $)$ and placed at $37-35^{\circ} \mathrm{C}$ for $24-18$ hours and heated. The turbidity of each cell was then checked. The lowest concentration of CFS that inhibited the visible growth of a microorganism were considered as MIC.

\subsection{Expression of target genes}

The expression levels of TDC, HDC, and rpoB (a housekeeping gene to normalize the expression levels of other genes) genes were determined by quantitative realtime PCR (qRT-PCR). The primers used for qRT-PCR are as follow: Forward 5'GAATTACCGATCTATGATGC3' and reverse 5'ACACCTTTGTTAGCACAAAC3' for HDC gene, forward 5' CGTTCACAATCAGTTCTT 3' and reverse 5' CCAACTTCTTCTTCCATTTG 'for TDC gene, forward 5'TTCTTACCGATCTATGCATG -3' and reverse 5' CCTTACATGCGTTAAAACCA 3'for $r p o B$ gene. Briefly, the total bacterial RNA of the 14 isolates was extracted through the use of a RNeasy Mini Kit (CinnaGen, Iran) and quantified by spectrometry (NanoDrop, Thermo Scientific, USA). Then, cDNA was synthesized using a Prime Script RT Reagent Kit (CinnaGen, Iran) and quantified using SYBR Green (Life Technologies). Ultimately, qRT-PCR was performed with a SYBR Premix Ex Taq II Kit (CinnaGen, Iran) on a thermocycler system (StepOneplus, Thermo Fisher Scientific, Germany) with an initial incubation at $95{ }^{\circ} \mathrm{C}$ for 125 seconds, followed by 40 cycles of $15 \mathrm{~s}$ at $94{ }^{\circ} \mathrm{C}$ and $1 \mathrm{~min}$ at $62^{\circ} \mathrm{C}$. The relative expression of the target genes was obtained using $r p o B$ housekeeping gene from $S$. aureus. The threshold cycle (CT) numbers were confirmed by the detection system software, and data were analyzed based on $\Delta \Delta \mathrm{Ct}$ method. The expression levels of target genes were specified and compared. Each reaction was carried out in triplicate, and statistical analysis was done via SPSS ver.16. Using SPSS, the correlations were calculated and the means were compared by t-test with a significance level of $\mathrm{P}<0.05$.

\section{Results}

Examination of raw milk samples showed that out of 100 samples, 34 were sterile, and in 66 samples, bacteria such as Staphylococcus species $(n=60)$, Escherichia coli $(n=4)$, and coliform $(n=2)$ were detected. This study focused on the levels of histamine and tyramine produced by staphylococci species; thus, the samples with Escherichia coli and coliforms were excluded.

\subsection{Multiplex PCR data}

The genomic study of the bacteria showed different types of Staphylococcus species, including Staphylococcus aureus, Staphylococcus hemolyticus, Staphylococcus saprophyticus, Staphylococcus epidermidis, Staphylococcus aureus, and Staphylococcus aureus (Figure 1). Examination of HDC and TDC genes in isolated species showed that 10 isolates had both genes, two isolates had HDC alone, and one had TDC alone (Figure 2).

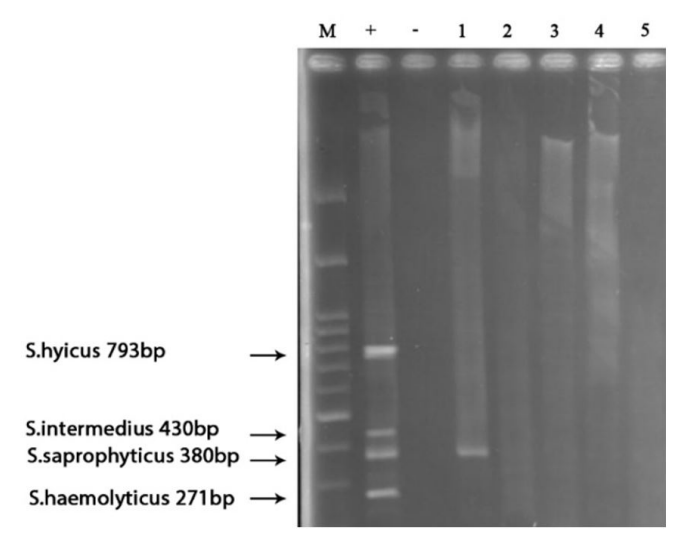

Figure 1. MultiplexPCR products electrophoresis of samples 1, 2, 3, 4 and 5. The M lane: 100 bp ladder, +: positive control, -: negative control.

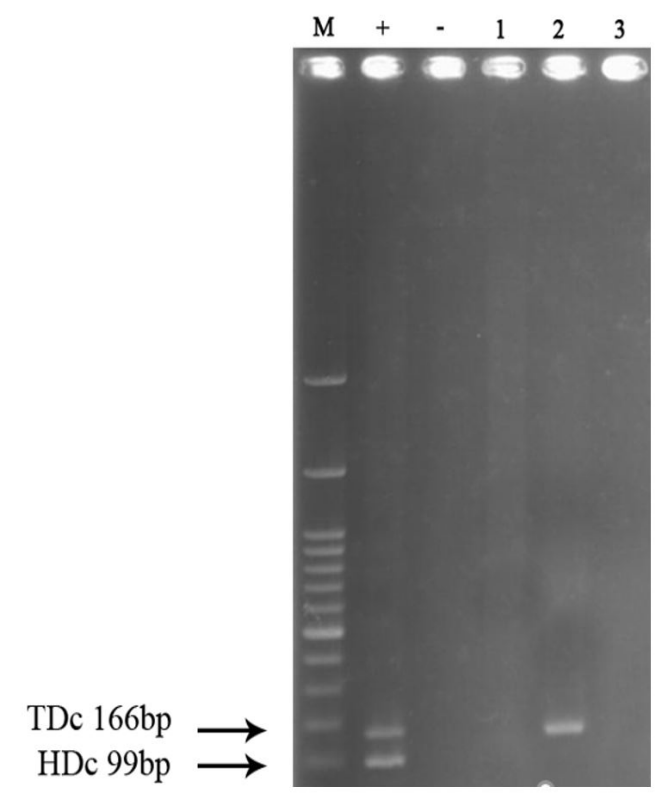

Figure 2. PCR products (HDC and TDC genes) electrophoresis of samples 1, 2 and 3. The M lane: 100 bp ladder, +: positive control, -: negative control. 


\subsection{HPLC data}

Based on the results, the levels of histamine and tyramine were higher in three samples (s44, s50, and s55) compared with other samples. Histamine and tyramine levels were significantly higher on the second and third days than on the first day $(\mathrm{P}<0.02)$. The data showed that after 48 hours, the levels of histamine in the foregoing samples were equal to 210,200 , and $200 \mathrm{ppb}$, and the levels of tyramine over the same period were $90 \mathrm{ppb}$ in all three samples. After 72 hours, tyramine levels increased only in one sample, reached $100 \mathrm{ppb}$, and remained unchanged in the other two samples (Figure 3).

\subsection{Antimicrobial activity of probiotics CFS}

The MIC obtained for Staphylococcus species treated with L. lactis CFS in samples 54, 40, and 44 were $125 \mu \mathrm{g} / \mathrm{mL}$, $62.5 \mu \mathrm{g} / \mathrm{mL}$ and $125 \mu \mathrm{g} / \mathrm{mL}$, respectively. The MIC results obtained for Staphylococcus species treated with B. bifidum CFS in samples 54, 44, and 40 were $62.5 \mu \mathrm{g} / \mathrm{mL}, 125 \mu \mathrm{g} / \mathrm{mL}$, and $125 \mu \mathrm{g} / \mathrm{mL}$, respectively.

\subsection{Gene expression}

We examined the effects of probiotic bacteria's CFS on gene expression, which may reveal the source of antimicrobial activity and suppression in biogenic amine production. Gene encoding for biogenic amine production was explored using real-time polymerase chain reaction (RT-PCR) following a $24 \mathrm{~h}$ exposure to varying concentrations of probiotics CFS. According to the findings, probiotics CFS induced suppression in $H D C$ and TDC genes $(\mathrm{p}<0.05)$. The expression of target genes was suppressed in three samples containing Staphylococcus species treated or not treated with B. bifidum CFS for Hdc and Tdc genes ( $\mathrm{p}=0.002$ and $\mathrm{p}=0.0012$, respectively). This indicates the significant decrease in gene expression due to treatment with B. bifidum. The rate of fold change for $H d c$ and $T d c$ gene in the mentioned groups was -1.241 and -1.322 , respectively. In addition, $t$-test showed that treatment of tyramine and histamine-producing bacteria with probiotic $L$. lactis CFS reduced the expression of $\mathrm{Hdc}(\mathrm{p}=0.007)$ and Tdc genes $(\mathrm{p}=0.008)$; therefore, their expression decreased (rate of fold change was -1.175 and -1.09 , respectively) (Figure 4 ).

\section{Discussion}

Biogenic amines are low-molecular-weight organic bases formed by microorganisms, such as $S$. aureus and Enterococci, with high proteolytic potential for the decarboxylation of histidine, tryptophan, phenylalanine, tyrosine, and lysine amino acids. High level of toxic biogenic amines of milk, such as Histamine and Tyramine, entails hypotension, headache, gastrointestinal complications, flushing, and allergic responses (Ma et al., 2020). Thus, it is necessary to monitor the biogenic amines in raw and processed milk due to their toxicity and usefulness as milk spoilage index. Bacterial decreasing methods for milk, such as high pressure, irradiation, pasteurization, or homogenization, diminish the levels of biogenic amine producing bacteria; however, there is evidence concerning contamination and production of biogenic amines in raw and processed milks (Gavina Manca et al., 2020; Poveda et al., 2020; Pivetta et al., 2020; Mousavi Khaneghah et al., 2020). In this study, in light of previous data supporting probiotics advantages, we examined the effects of L. lactis and B. bifidum (two probiotic bacteria) on the HDC and TDC genes of Staphylococcus species isolated from raw milk. Our data showed that the two probiotic bacteria
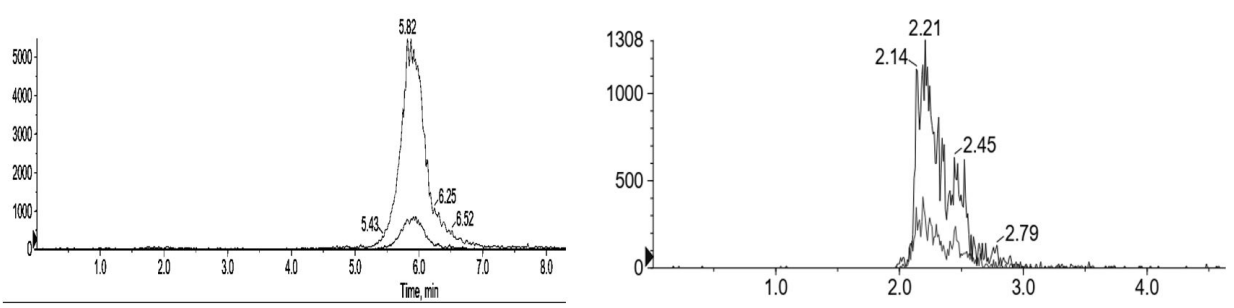

Figure 3. HPLC analysis of the sample with the highest amount of histamine 48 hours after sampling (left); HPLC analysis of the sample with the highest amount of tyramine 72 hours after sampling (right).

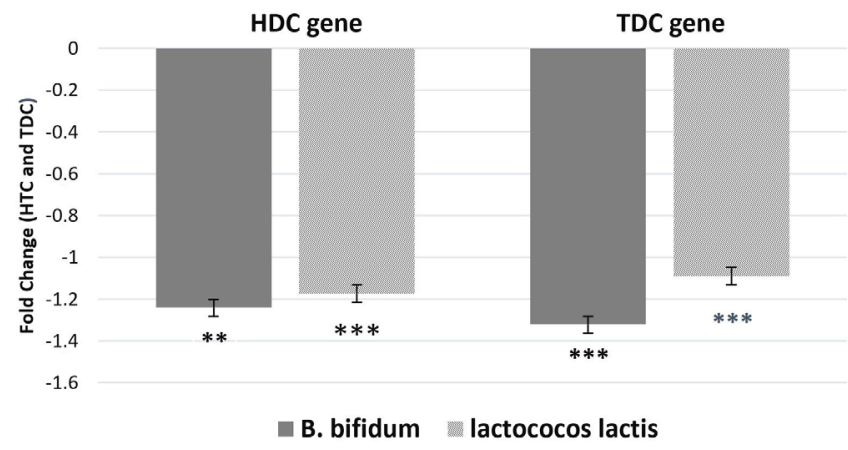

Figure 4. Quantitative real-time PCR showing fold changed of TDC and HDC genes in CFS treated strains that calculated by the $2 \Delta \Delta C T$ method. Data represent the averages from three independent experiments. Error bars represent the standard deviations from the means. ${ }^{* *} \mathrm{P} 0.05$; ${ }^{* *} \mathrm{P}$ 0.005 versus control group. 
significantly reduced the expression level of tyramine decarboxylase and histamine decarboxylase genes involved in the generation of biogenic amines.

The difference among Staphylococcus isolates in terms of amino acid decarboxylase activity is in accordance with previous studies (Anderegg et al., 2020; Sang et al., 2020) which reported that the production of biogenic amines could vary significantly at the isolate level. Our data confirmed that the production of biogenic amine is an isolated specific trait as reported earlier (Jeong et al., 2014; Poveda et al., 2020). A wide range of data has been reported on the production of biogenic amines by staphylococcal isolates.

Using ELISA method, Mohtadi nia et al. (2014) evaluated the histamine content of 60 canned tuna fish samples supplied by the supermarkets in Tabriz city in order to study this biogenic amine as an important spoilage indicator. Their results showed the statistically significant amount of histamine in canned tuna produced in the southern and northern regions of the country. They also showed that canned tuna produced in summer and fall had the highest and lowest levels of histamine, respectively. Finally, they concluded that because a high percentage of canned food contain high concentrations of histamine, there is a risk of histamine poisoning for the consumers. Similarly, in the present study, a significant percentage of the samples contained bacteria that produced biogenic amines, generating different percentages of histamine and tyramine in the milk.

Some studies have confirmed that the production of biogenic amines is not associated with the presence of a specific amino acid decarboxylase gene (Jeong et al., 2014); others have reported that the lack of correlation between the presence of genetic determinants and production of biogenic amines is attributed to the use of non-staphylococcal species primer in PCR (Poveda et al., 2020). Our study revealed a linear correlation between the existence of TDC and HDC genes and production of target biogenic amines, which could be due to the staphylococcal specific primers used in PCR reaction.

In another study by Shekarforoush et al. (2018), the capillary zone electrophoresis method with absorption detector (CZE) was compared with the high-performance liquid chromatography (HPLC) method to measure the amount of histamine in microbial culture medium. For this purpose, the culture medium was inoculated with the standard strain of histamine-producing Staphylococcus epidermidis TYH1 and two strains of Staphylococcus capitis and Staphylococcus carnosus containing the histidine decarboxylase gene. The amount of histamine generated by three bacterial strains (measured by the two methods) was not statistically significant. Due to the similar findings in the two methods, HPLC was proposed as a golden approach to measuring the amount of histamine in microbial culture media (Shekarforoush et al., 2018). Razavi et al. (2013) evaluated the amount of histamine in Koopeh cheese as one of the most popular types of traditional cheese made from raw milk in West-Azerbaijan province, Iran. Experiments performed by HPLC method on 70 samples of traditional Koopeh cheese revealed that the least amount of histamine was $2.43 \mathrm{ppm}$ and the highest value was estimated at $1102.24 \mathrm{ppm}$. Costa et al. (2015) also proved HPLC efficacy in biogenic amine measurement of milk. These studies indicate the validity of HPLC in measuring biogenic amines, which is in line with our findings. In 2017, Septiana et al. (2017) demonstrated that endophytic fungi with turmeric (Curcuma longa L.) were able to inhibit histamine-producing bacteria in fish. This study showed that Lactobacillus casei and B. bifidum probiotic were effective in inhibiting Staphylococcus bacteria. In the present study, Lactococcus lactis and Bifidobacterium bifidum CFS had the ability to inhibit the growth and production of biogenic amines through inhibiting the expression of genes involved in Staphylococcus bacteria isolated from milk. Based on the results of the present study, it should be emphasized that among the isolates comprising the indigenous staphylococcal population in bulk tank ewe's milk, there are biogenic amine strains harboring possibly harmful histamine and tyramine genes.

\section{Conclusion}

Histamine and tyramine, the most important amines of milk from a safety perspective, were found to be eliminated and diminished by L. lactis and B. bifidum probiotics cell free supernatant. It will also be effective to reduce the population of bacteria that produce biogenic amines through the use of some solutions. This study showed that the use of probiotic bacteria can reduce the generation of these harmful amines via decreasing the expression of tyramine and histamine-producing genes and bacterial population.

\section{Acknowledgements}

Technical support for the thesis accomplishment by the Islamic Azad University is gratefully acknowledged.

\section{References}

Acu, M., Kinik, O., \& Yerlikaya, O. (2021). Probiotic viability, viscosity, hardness properties and sensorial quality of synbiotic ice creams produced from goat's milk. Food Science and Technology, 41(1), 167-173. http://dx.doi.org/10.1590/fst.39419.

Akarca, G. (2020). Lipolysis and aroma occurrence in Erzincan Tulum cheese, which is produced by adding probiotic bacteria and ripened in various packages. Food Science and Technology, 40(1), 102-116. http://dx.doi.org/10.1590/fst.33818.

Amelia, R., Philip, K., Pratama, Y. E., \& Purwati, E. (2021). Characterization and probiotic potential of lactic acid bacteria isolated from dadiah sampled in West Sumatra. Food Science and Technology. In press. http://dx.doi.org/10.1590/fst.30020.

Anderegg, J., Fischer, M., Dürig, J., Die, A., Lacroix, C., \& Meile, L. (2020). Detection of biogenic amines and tyramine-producing bacteria in fermented sausages from Switzerland. Journal of Food Protection, 83(9), 1512-1519. http://dx.doi.org/10.4315/JFP-19-468. PMid:32338740.

Capozzi, V., Russo, P., Ladero, V., Fernández, M., Fiocco, D., Alvarez, M. A., Grieco, F., \& Spano, G. (2012). Biogenic amines degradation by Lactobacillus plantarum: toward a potential application in wine. Frontiers in Microbiology, 3, 122. http://dx.doi.org/10.3389/ fmicb.2012.00122. PMid:22485114.

Costa, M. P., Balthazar, C. F., Rodrigues, B. L., Lazaro, C. A., Silva, A. C., Cruz, A. G., \& Conte, C. A. Jr. (2015). Determination of biogenic amines by high-performance liquid chromatography (HPLC-DAD) in probiotic cow's and goat's fermented milks and acceptance. Food 
Science \& Nutrition, 3(3), 172-178. http://dx.doi.org/10.1002/ fsn3.200. PMid:25987991.

Durak-Dados, A., Michalski, M., \& Osek, J. (2020). Histamine and other biogenic amines in food. Journal of Veterinary Research, 64(2), 281-288. http://dx.doi.org/10.2478/jvetres-2020-0029.

Elsanhoty, R. M., \& Ramadan, M. F. (2016). Genetic screening of biogenic amines production capacity from some lactic acid bacteria strains. Food Control, 68, 220-228. http://dx.doi.org/10.1016/j. foodcont.2016.04.002.

Fong, F. L. Y., Lam, K. Y., San Lau, C., Ho, K. H., Kan, Y. H., Poon, M. Y., El-Nezami, H., \& Sze, E. T. P. (2020). Reduction in biogenic amines in douchi fermented by probiotic bacteria. PLoS One, 15(3), e0230916. http://dx.doi.org/10.1371/journal.pone.0230916. PMid:32214369.

Gavina Manca, A. R., Siddi, G., Mocci, A. M., Murittu, G., \& De Santis, P. L. (2020). Biogenic amines content in Fiore Sardo cheese in relation to free amino acids and physicochemical characteristics. Italian Journal of Food Safety, 9(1), 8457. http://dx.doi.org/10.4081/ ijfs.2020.8457. PMid:32300567.

Gonçalves, B. L., Uliana, R. D., Coppa, C. F. S. C., Lee, S. H. I., Kamimura, E. S., Oliveira, C. A. F., \& Corassin, C. H. (2020). Aflatoxin M1: biological decontamination methods in milk and cheese. Food Science and Technology. In press. http://dx.doi.org/10.1590/fst.22920.

Jeong, D.-W., Han, S., \& Lee, J.-H. (2014). Safety and technological characterization of Staphylococcus equorum isolates from jeotgal, a Korean high-salt-fermented seafood, for starter development. International Journal of Food Microbiology, 188, 108-115. http:// dx.doi.org/10.1016/j.ijfoodmicro.2014.07.022. PMid:25106039.

Kerry, R. G., Patra, J. K., Gouda, S., Park, Y., Shin, H.-S., \& Das, G. (2018). Benefaction of probiotics for human health: a review. Journal of Food and Drug Analysis, 26(3), 927-939. http://dx.doi. org/10.1016/j.jfda.2018.01.002. PMid:29976412.

Khiralla, G. M., Mohamed, E. A., Farag, A. G., \& Elhariry, H. (2015). Antibiofilm effect of Lactobacillus pentosus and Lactobacillus plantarum cell-free supernatants against some bacterial pathogens. Journal of Biotech Research, 6, 86.

Knysh, O., \& Martynov, A. (2020). The effect of Bifidobacterim bifidum cell-free supernatants, ascorbic acid, fructose, sorbitol, xylitol and stevia on the daily biomass growth of opportunistic microorganisms. Annals of Mechnikov's Institute, (2), 71-76.

Lucatto, J. N., Silva-Buzanello, R. A., Mendonça, S. N. T. G., Lazarotto, T. C., Sanchez, J. L., Bona, E., \& Drunkler, D. A. (2020). Performance of different microbial cultures in potentially probiotic and prebiotic yoghurts from cow and goat milks. International Journal of Dairy Technology, 73(1), 144-156. http://dx.doi.org/10.1111/1471-0307.12655.

Luengo, J. M., \& Olivera, E. R. (2020). Catabolism of biogenic amines in Pseudomonas species. Environmental Microbiology, 22(4), 11741192. http://dx.doi.org/10.1111/1462-2920.14912. PMid:31912965.

Ma, J.-K., Raslan, A. A., Elbadry, S., El-Ghareeb, W. R., Mulla, Z. S., Bin-Jumah, M., Abdel-Daim, M. M., \& Darwish, W. S. (2020). Levels of biogenic amines in cheese: correlation to microbial status, dietary intakes, and their health risk assessment. Environmental Science and Pollution Research International, 27(35), 44452. http://dx.doi. org/10.1007/s11356-020-10401-2. PMid:32770334.

Mituniewicz-Małek, A., Zielińska, D., \& Ziarno, M. (2019). Probiotic monocultures in fermented goat milk beverages-sensory quality of final product. International Journal of Dairy Technology, 72(2), 240-247. http://dx.doi.org/10.1111/1471-0307.12576.

Mohtadi nia, J., Zakerzadeh, M., Goudarzi, M., Rahman Pour, H., \& Khadem Haghighian, H. (2014). Determining the amount of histamine levels in canned tuna fish marketed in supermarkets of
Tabriz City. Journal of Fasa University of Medical Sciences, 4(2), 201208. Retrieved from http://journal.fums.ac.ir/article-1-288-fa.html

Motaghifar, A., Akbari-Adergani, B., Rokney, N., \& Mottalebi, A. (2020). Evaluating red meat putrefaction in long term storage in freezing condition based on co-variation of major biogenic amines and Total Volatile Nitrogen. Food Science and Technology. In press. http://dx.doi.org/10.1590/fst.08120.

Mousavi Khaneghah, A., Abhari, K., Eş, I., Soares, M. B., Oliveira, R. B. A., Hosseini, H., Rezaei, M., Balthazar, C. F., Silva, R., Cruz, A. G., Ranadheera, C. S., \& Sant'Ana, A. S. (2020). Interactions between probiotics and pathogenic microorganisms in hosts and foods: a review. Trends in Food Science \& Technology, 95, 205-218. http:// dx.doi.org/10.1016/j.tifs.2019.11.022.

Pivetta, F. P., Silva, M. N., Tagliapietra, B. L., \& Richards, N. S. S. (2020). Addition of green banana biomass as partial substitute for fat and encapsulated Lactobacillus acidophilus in requeijão cremoso processed cheese. Food Science and Technology, 40(2), 451-457. http://dx.doi. org/10.1590/fst.03919.

Poveda, J. M., Jiménez, L., Perea, J. M., Arias, R., \& Palop, M. L. (2020). farming practices influence antibiotic resistance and biogenic amine capacity of Staphylococci from bulk tank ewe's milk. Animals, 10(9), 1622. http://dx.doi.org/10.3390/ani10091622. PMid:32927840.

Prezzi, L. E., Lee, S. H., Nunes, V. M., Corassin, C. H., Pimentel, T. C., Rocha, R. S., Ramos, G. L. P. A., Guimarães, J. T., Balthazar, C. F., Duarte, M. C. K. H., Freitas, M. Q., Esmerino, E. A., Silva, M. C., Cruz, A. G., \& Oliveira, C. A. F. (2020). Effect of Lactobacillus rhamnosus on growth of Listeria monocytogenes and Staphylococcus aureus in a probiotic Minas Frescal cheese. Food Microbiology, 92, 103557. http://dx.doi.org/10.1016/j.fm.2020.103557. PMid:32950151.

Ranadheera, C., Evans, C., Baines, S., Balthazar, C. F., Cruz, A. G., Esmerino, E. A., Freitas, M. Q., Pimentel, T. C., Wittwer, A., Naumovski, N., Graça, J. S., Sant'Ana, A. S., Ajlouni, S., \& Vasiljevic, T. (2019). Probiotics in goat milk products: Delivery capacity and ability to improve sensory attributes. Comprehensive Reviews in Food Science and Food Safety, 18(4), 867-882. http://dx.doi.org/10.1111/15414337.12447. PMid:33337004.

Razavi, R. S., Hassanzadazar, H., \& Aliakbarlu, J. (2013). Histamine determination in Koopeh cheese in West-Azerbaijan province by HPLC. Food Hygiene, 3(1), 9.

Ruiz-Capillas, C., \& Herrero, A. M. (2019). Impact of biogenic amines on food quality and safety. Foods, 8(2), 62. http://dx.doi.org/10.3390/ foods8020062. PMid:30744001.

Sang, X., Li, K., Zhu, Y., Ma, X., Hao, H., Bi, J., Zhang, G., \& Hou, H. (2020). The impact of microbial diversity on biogenic amines formation in grasshopper sub shrimp paste during the fermentation. Frontiers in Microbiology, 11, 782. http://dx.doi.org/10.3389/ fmicb.2020.00782. PMid:32390997.

Septiana, E., Sukarno, N., Sukarno, \& Simanjuntak, P. (2017). Endophytic fungi associated with turmeric (Curcuma longa L.) Can inhibit histamine-forming bacteria in fish. Hayati Journal of Biosciences, 24(1), 46-52. http://dx.doi.org/10.1016/j.hjb.2017.05.004.

Shabbir, M. A., Ahmed, H., Maan, A. A., Rehman, A., Afraz, M. T., Iqbal, M. W., Khan, I. M., Amir, R. M., Ashraf, W., Khan, M. R., \& Aadil, R. M. (2020). Effect of non-thermal processing techniques on pathogenic and spoilage microorganisms of milk and milk products. Food Science and Technology. In press. http://dx.doi. org/10.1590/fst.05820.

Shekarforoush, S., Aminlari, M., \& Hosseinzadeh, S. (2018). Comparison of capillary zone electrophoresis and high-performance liquid chromatography for the determination of histamine in bacterial culture media. Journal of Food Hygiene, 8(1), 29. 
Siang, S. C., Wai, L. K., Lin, N. K., \& Phing, P. L. (2019). Effect of added prebiotic (Isomalto-oligosaccharide) and Coating of Beads on the Survival of Microencapsulated Lactobacillus rhamnosus GG. Food Science and Technology, 39(2, Suppl. 2), 601-609. http://dx.doi. org/10.1590/fst.27518.

Zendeboodi, F., Khorshidian, N., Mortazavian, A. M., \& da Cruz, A. G. (2020). Probiotic: conceptualization from a new approach. Current Opinion in Food Science, 32, 103-123. http://dx.doi.org/10.1016/j. cofs.2020.03.009.
Zhang, Z., Lv, J., Pan, L., \& Zhang, Y. (2018). Roles and applications of probiotic Lactobacillus strains. Applied Microbiology and Biotechnology, 102(19), 8135-8143. http://dx.doi.org/10.1007/s00253-018-9217-9. PMid:30032432.

Zhao, J., Niu, C., Du, S., Liu, C., Zheng, F., Wang, J., \& Li, Q. (2020). Reduction of biogenic amines formation during soybean paste fermentation by using Staphylococcus carnosus M43 and Pediococcus acidilactici M28 as starter culture. LWT - Food Science and Technology, 133, 109917. http://dx.doi.org/10.1016/j.lwt.2020.109917. 